\title{
How is Escherichia coli Doing?
}

\section{Edward Lai*}

Professor, Department of Chemistry, Carleton University, Ontario, Canada
Most of us have come to join this world of biochemical sciences in hopes of pursuing research that will have an impact on peoples' daily lives. The Escherichia coli (E. coli) bacterium has been intensively investigated for over 60 years [1] and is the most widely studied prokaryotic model organism of importance to the fields of biotechnology and microbiology. It has served as the host organism for the majority of work with recombinant DNA [2], and may be considered a simplified form of the heat shock response common to all living cells [3]. The question for all researchers is whether $E$. coli can continue to attract government funding for basic research of academic interest.

Enterohemorrhagic Escherichia coli (EHEC) have been recognized as a cause of serious illness and mortality in outbreaks of foodborne illness [4,5]. Most pathogenic strains behave biochemically and ecologically like any other non-pathogenic E. coli, making their detection among commensal E. coli, an challenging problem. E. coli $\mathrm{O} 157: \mathrm{H7}$ is a foodborne pathogen causing hemorrhagic colitis, which is sometimes complicated by haemolyticuraemic syndrome or thrombotic thrombocytopenic purpura. Available evidence regarding whether antibiotics were effective or harmful for the treatment of patients infected with E. coli O157:H7 was reviewed by Panos et al. [6]. Agricultural practices with emphasis on leafy green vegetables and preharvest interventions against E.coli $\mathrm{O} 157$ by vaccine treatment of cattle [7] are two effective control strategies. Unfortunately the problem is at large and other pathogenic E. coli strains are also known to cause foodborne and waterborne illnesses.

In the United States and Canada, the presence of pathogenic $E$. coli in foods and water is highly regulated. The methodology used for detection of these organisms is a key issue, as discussed by Grant et al. [8] from a public health point of view. The enrichment protocol, detection and isolation procedure in the U.S. FDA BAM have been shown effective for E. coli O157:H7 in a wide variety of foods [8]. Buffered peptone water supplemented with cefixim-tellurite and acriflavin was shown to optimize the growth of $E$. coli inoculated in the cheeses tested. With a low inoculum level (1-10 cfu per $25 \mathrm{~g})$ in the cheeses, E. coli counts reached at least $5 \times 10^{4} \mathrm{cfu} / \mathrm{mL}$ after $24 \mathrm{~h}$ of incubation [9]. A novel method of detecting $E$. coli has just been reported by Duplan et al. [10] using photoluminescence of quantum semiconductor devices functionalized with two different antibody-based architectures. The detection of $\mathrm{E}$.coli at $10^{4} \mathrm{cfu} / \mathrm{mL}$ was achieved after 2 hours of exposure to the bacteria. Lee and Levin [11] developed a method that separate E. coli from lettuce and remove inhibitors, allowing $5 \mathrm{cfu} / \mathrm{g}$ of target cells to be detected using real-time polymerase chain reaction (PCR). An electrochemical DNA biosensor was developed by Li et al. [12] for amperometric detection of $E$. coli. It is based on a sandwich detection strategy which involves the capture probe immobilized onFe, $\mathrm{O}_{3} @ \mathrm{Au}$ core/shell nanoparticles, target, and reporter probe labeled with horse radish peroxidase. The biosensor detects concentrations higher than $500 \mathrm{cfu} / \mathrm{mL}$ of $E$. coli without any nucleic acid amplification, or the detection limit can be lowered to $5 \mathrm{cfu} / \mathrm{mL}$ after 4 hours of incubation. An immunomagnetic bead-immunoliposome fluorescence assay took DeCory et al. [13] only $8 \mathrm{~h}$ to detect $1 \mathrm{cfu} / \mathrm{mL}$ of $E$. coli in aqueous samples. Anotherassay was designed by Kamma et al. [14] with anti-E. coli monoclonal antibody bound to $0.2 \mu \mathrm{m}$ nitrocellulose filter disk as the capture. A water sample was filtered to capture E. coli on the disk. Detection of the pathogen was accomplished by using the same antibody to form a homosandwich. After 5 h, 1-5 cfu of E. coli could be detected in $100 \mathrm{~mL}$ of water sample.

A genomic fingerprinting method was commonly used to discriminate fecal E. coli strains from cows, chickens and humans by their BOX-PCR profiles [15]. Regarding bacterial source tracking, Fourier transform infrared (FTIR) micro-spectroscopy was demonstrated by Carlos et al. [16] to be a suitable tool for fecal E. coli discrimination. Using the second derivate of FTIR spectral bands (in the 2816-3026 $\mathrm{cm}-1$ region for fatty acids) and orthogonal signal correction, correct discrimination of all the E. coli strains was attained. UCLA researchers have developed a new fluorescent imaging and sensing platform that can detect the presence of E. coli in food and water. They combined antibody functionalized glass capillaries with quantum dots as signal reporters to specifically detect $E$. coli cells in liquid samples using a compact attachment to a cell-phone camera [17].

Academic interest in E. coli is abundantly evidenced by the flurries of biochemistry research activity. $\mathrm{Li}$ [18] reviewed commonly used strategies for antimicrobials production against E. coli, discussing various approaches and possible optimizations at different stages. Torres-Costa et al. [19] reported on the fabrication of patterned and textured surfaces at micron and nano-scale levels, respectively, with very different chemical and topographic characteristics to control cell-substrate interactions. Cui et al. [20] examined the molecular mechanism of gold nanoparticles that showed potent antibacterial activities against multidrug-resistant $E$. coli by transcriptomic and proteomic actions. Their investigation results would allow the development of antibacterial agents that target the energy-metabolism and transcription of bacteria, without triggering the reactive oxygen species reaction that may be harmful to the host. Kim et al. [21] assessed the microbial effect of silver nanoparticles on $E$. coli via three different assays: a growth inhibition assay, a colony forming unit assay, and a liquid-to-plate assay. Bacterial sensitivity to silver nanoparticles was found to be dependent on the microbial assay employed. Dissolution of silver from the nanoparticles could not explain the observed toxicity, and they detected clear evidence of silver nanoparticles uptake by the cells. As extensive application of $\gamma-\mathrm{Fe}_{2} \mathrm{O}_{3}$ magnetic nanoparticles (MNPs) increased their potential risk on environment and human health, He et al. [22] reported a genetic impact of these nanoparticles on E. coli. After 3000-generation incubation with MNPs addition,

*Corresponding author: Edward Lai, Professor, Department of Chemistry, Carleton University, Ontario, Canada, E-mail: edward_lai@carleton.ca

Received February 27, 2012; Accepted February 29, 2012; Published March 02, 2012

Citation: Lai E (2012) How is Escherichia coli Doing? Biochem Anal Biochem 1:e103. doi:10.4172/2161-1009.1000e103

Copyright: (c) 2012 Lai E. This is an open-access article distributed under the terms of the Creative Commons Attribution License, which permits unrestricted use, distribution, and reproduction in any medium, provided the original author and source are credited. 
obvious genomic variations were revealed by using repetitive extragenic palindromic PCR DNA fingerprint technique. Transmission electronic microscopy and flow cytometry analysis consistently demonstrated the occurrences of adsorption and membrane-internalization of MNPs outside and inside the cells. The uptake of MNPs facilitated Fe binding with proteins and DNA strands, enhancing the mutation frequency of E. coli.

The Ahmed Zewail Prize in Molecular Sciences is awarded by Elsevier on a biennial basis to individual scientists who have made significant and creative contributions, particularly those of a fundamental nature, to any of the disciplines of molecular sciences [23]. The awardee's research activities may cover theoretical and/or experimental aspects of studies in all phases of matter and biological systems. Prof. David Buckingham was awarded the first Ahmed Zewail Prize for his pioneering research that provided a fundamental understanding of how molecules are perturbed by electromagnetic radiation, magnetic and electric fields, and other molecules [24]. The second Ahmed Zewail Prize was awarded to Prof. Mostafa El-Sayedfor his pioneering experiments that yielded deeper understanding of the mechanisms of electronic dynamics, at different length scales ranging from nanoparticles to photo-biological systems. Last March, Professor William H. Miller from the University of California, Berkeley, USA, won the third Ahmed Zewail Prize for his outstanding contributions to molecular collision theory and chemical reaction dynamics. Many biochemists have made fundamental contributions to the field of $E$. coli research. In their works, we can see many creative sparks often in an elegant approach. Some of these are definitely seminal marks of novelty. We are looking forward to new analytical biochemistry of using E. coli bacteria for binding toxic nanomaterials in water, as well as topics like "Interdisciplinary Approach to Understanding the Complex Propagation Mechanism of E. coli O157:H7 Living Cells on Antimicrobial Nanostructured Food Packaging Film Surface" within food microbiology research. My sincere wish is going towards them all for higher recognition of their E. coli research contributions by a prestigious award or more in the coming years. Open access journals are important to this expanding field for rapid review and publication of manuscripts. The OMICS publishing group offers several beneficial dissemination features, including user-friendly website translation of a published article to more than 50 languages. The reader can choose any one language to read the article, which enables worldwide communication of our scientific findings with researchers working in a variety of national languages.

\section{References}

1. http://en.wikipedia.org/wiki/Pathogenic_Escherichia_coli

2. Bronstein JC, Olson SL, LeVier K, Tomilo M, Weber PC (2004) Purification and characterization of recombinant Staphylococcus haemolyticus DNA gyrase and topoisomerase IV expressed in Escherichia coli. Antimicrob Agents Chemother 48: $2708-2711$

3. Lüders S, Fallet C, Franco-Lara E (2009) Proteome analysis of the Escherichia coli heat shock response under steady-state conditions. Proteome Sci 7: 36.

4. Karch H, Tarr PI, Bielaszewska M (2005) Enterohaemorrhagic Escherichia coli in human medicine. Int J Med Microbiol 295:405-418.

5. Viazis S, Diez-Gonzalez F (2011) Chapter one - Enterohemorrhagic Escherichia coli: The Twentieth Century's Emerging Foodborne Pathogen: A Review. Advances in Agronomy 111: 1-50.

6. Panos GZ, Betsi GI, Falagas ME (2006) Systematic review: are antibiotics detrimental or beneficial for the treatment of patients with Escherichia coli 0157:H7 infection? Aliment Pharmacol Ther 24: 731-742.

7. Snedeker KG, Campbell M, Sargeant JM (2012) A Systematic Review of Vaccinations to Reduce the Shedding of Escherichia coli O157 in the Faeces of Domestic Ruminants. Zoonoses Public Health 59: 126-138.
8. Fedio WM, Jinneman KC, Yoshitomi KJ, Zapata R, Weagant SD (2012) Efficacy of a post enrichment acid treatment for isolation of Escherichia coli O157:H7 from alfalfa sprouts. Food Microbiol 30: 83-90.

9. Savoye F, Rozand C, Bouvier M, Gleizal A, Thevenot D (2011) Optimized enrichment for the detection of Escherichia coli 026 in French raw milk cheeses. Lett Appl Microbiol 52: 603-609.

10. Duplan V, Frost E, Dubowski JJ (2011) A photoluminescence-based quantum semiconductor biosensor for rapid in situ detection of Escherichia coli. Sensors and Actuators B: Chemical 160: 46-51.

11. Lee JL, Levin RE (2011) Detection of 5 CFU/g of Escherichia coli O157:H7 on lettuce using activated charcoal and real-time PCR without enrichment. Food Microbiol 28: 562-567.

12. Li K, Lai Y, Zhang W, Jin L (2011) Fe2O3@Au core/shell nanoparticle-based electrochemical DNA biosensor for Escherichia coli detection. Talanta 84: 607613

13. DeCory TR, Durst RA, Zimmerman SJ, Garringer LA, Paluca G, et al. (2005) Development of an immunomagnetic bead-immunoliposome fluorescence assay for rapid detection of Escherichia coli 0157:H7 in aqueous samples and comparison of the assay with a standard microbiological method. Appl Environ Microbiol 71: 1856-1864

14. Kamma S, Tang L, Leung K, Ashton E, Newman N, et al. (2008) A rapid two dot filter assay for the detection of $E$. coli $\mathrm{O} 157$ in water samples. $\mathrm{J}$ Immunol Methods 336: 159-165

15. Cesaris L, Gillespie BE, Srinivasan V, Almeida RA, Zecconi A, et al. (2007) Discriminating between strains of Escherichia coli using pulsed-field ge electrophoresis and BOX-PCR. Foodborne Pathog Dis 4: 473-480.

16. Carlos C, Maretto DA, Poppi RJ, Sato MIZ, Ottoboni LMM (2011) Fourier transform infrared microspectroscopy as a bacterial source tracking tool to discriminate fecal $E$. coli strains. Microchemical Journal 1: 15-19.

17. Engineers create cell phone-based sensor for detection of E. coli.

18. Li Y (2011) Recombinant production of antimicrobial peptides in Escherichia coli : A review. Protein Expr Purif 2: 260-267.

19. Torres-Costa V, Martínez-Muñoz G, Sánchez-Vaquero V, Muñoz-Noval A González-Méndez L, et al. (2012) Engineering of silicon surfaces at the microand nanoscales for cell adhesion and migration control. Int J Nanomedicine 7 : 623-630.

20. Cui Y, Zhao Y, Tian Y, Zhang W, Lü X, et al. (2012) The molecular mechanism of action of bactericidal gold nanoparticles on Escherichia coli. Biomaterials 7 2327-2333.

21. Kim SW, Baek YW, An YJ (2011) Assay-dependent effect of silver nanoparticles to Escherichia coli and Bacillus subtilis. Appl Microbiol Biotechnol 92: 10451052.

22. He S, Feng Y, Gu N, Zhang Y, Lin X (2011) The effect of $y$-Fe2O3 nanoparticles on Escherichia coli genome. Environ Pollut 159: 3468-3473.

23. Ahmed Zewail Prize in Molecular Sciences.

24. Previous Winners - Ahmed Zewail Prize in Molecular Sciences. 